\title{
Penerapan Portable Smartwater Treatment Untuk Meningkatkan Produksi Telur Peternak Ayam Petelur Martapura Kalimantan Selatan Dodon Turianto Nugrahadi', Liling Triyasmono²,
}

Progam Studi Ilmu Komputer, FMIPA ULM

Yani Km 36.5, Banjarbaru, Kalimantan Selatan

1dodonturianto@ulm.ac.id

Progam Studi Farmasi, FMIPA ULM

Yani Km 36.5, Banjarbaru, Kalimantan Selatan

2liling2382imeru@gmail.com

Artikel diterima: 08-10-2019, direvisi: 13-11-2019, diterbitkan: 25-12-2019

\begin{abstract}
Abstrak
Masyarakat Kalimantan Selatan menggunakan air sungai Martapura dan air sumur untuk memenuhi kebutuhan airnya, salah satunya pada sektor peternakan ayam petelur. Namun, air yang dipakai masyarakat tersebut, airnya keruh dan berbau sehingga berbahaya bagi kesehatan ternak bila dikonsumsi terus. Selain itu, kualitas air bersih sangat berpengaruh terhadap tingkat kesehatan ayam petelur, serta hasil kualitas dan kuantitas produksi ayam petelur. Penggunaan air sungai Martapura dan sumur oleh para peternak ayam petelur di Desa Sungai Sipai Kecamatan Martapura telah berlangsung selama lama perlu solusi alternatif lain untuk mendapatkan air bersih. Maka, Portable Smart Water Treatment menjadi salah satu solusi untuk mengatasi masalah tersebut. Alat ini dibuat berdasarkan kebutuhan akan alat yang portabel, praktis, dan ekonomis, namun memiliki debit $1-5$ liter/menit. Alat ini dilengkapi dengan panel surya dan sistem kontrol otomatis. Hasil kegiatan menunjukan bahwa terpenuhinya kebutuhan air bersih bagi peternak ayam petelur dengan teknologi filtrasi, serta meningkatkan produksi sebesar $5 \%$.
\end{abstract}

Kata Kunci: Air bersih, Ayam petelur, Portable Smart Water Treatment

\begin{abstract}
The people of South Kalimantan using water from Martapura river and water wells for their water needs, one of which is in the laying hens farming sector. However, water that people use are muddy and smelly so it will danger for healty of laying hen. In addition, the quality of fresh water is very influential on the level of health of laying hens, as well as the results of the quality and quantity of laying hens productionwater.

the use of Martapura river water and wells for laying hens breeders in Sungai Sipai Village, Martapura District has been happen for a long time, so it is need other alternative solution to get fresh water. Portable Smart Water Treatment is one of solution to resolve that problem. This tool is made based on the need that must be portable, practical, and economical, but have a debit of 1-5 liters / minute. This tool is equipped with solar panels and automatic control systems. The results of the activity showed that fresh water for laying hens was fulfillment by filtration technology, and it is increasing production by $5 \%$.
\end{abstract}

Keyword: fresh water, Laying hens, Portable Smart Water Treatment, Solar Cell 


\section{Pendahuluan}

Air merupakan salah satu faktor yang sangat penting bagi masyarakat khususnya Masyarakat Kalimantan Selatan dengan menggunakan air sungai Martapura dan air kolam (sumur) yang merupakan air gambut untuk memenuhi kebutuhan airnya. Namun, air gambut yang dipakai masyarakat airnya keruh dan berbau sehingga berbahaya bagi kesehatan bila dikonsumsi terus menerus. Pengkonsumsian ini pun terjadi pada sektor peternakan. Penggunaan air sungai Martapura dan sumur gambut oleh para peternak ayam petelur di desa Sungai Sipai Kecamatan Martapura Kabupaten Banjar Kalimantan Selatan telah berlangsung selama bertahuntahun sehingga ini sangat berpengaruh pada kualitas dan kuantitas produksi dari peternakan ayam petelur di daerah tersebut.

Hasil pengujian kualitas air sungai Martapura oleh BAPEDALDA Kabupaten Banjar yang bekerja sama dengan Balai Riset dan Standarisasi Industri Kalimantan Selatan pada bulan januari 2017 memperlihatkan bahwa kondisinya telah tercemar, baik secara fisika, kimia, maupun biologi. Hal ini ditunjukan dengan kandungan TSS 224 mg/l, COD 15,4 mg/L, dan BOD 7,5 mg/L, yang telah melebihi ambang batas peruntukan dan baku mutu air kelas I.

Keadaan ini bila dibiarkan berlarut-larut akan menimbulkan dampak yang sangat serius bagi penurunan kualitas dan kuantitas produksi ayam petelur, dan inipun akan berimbas pada penurunan tingkat ekonomi masyarakat. Dalam jangka pendek, dapat berpengaruh terhadap tingkat produksi ayam petelur sehingga tidak dapat memaksimalkan tingkat ekonomi sektor peternakan ayam petelur. Dalam jangka panjang, dikhawatirkan akan berpengaruh terhadap penurunan kualitas hasil produksi ayam petelur, sehingga dapat berpengaruh pada masyarakat pengkonsumsi telur dari peternak ayam petelur.

Energi baru dan terbarukan mempunyai peran yang sangat penting dalam memenuhi kebutuhan energi. Indonesia yang merupakan daerah tropis mempunyai potensi energi matahari sangat besar, sehingga dapat digunakan sebagai alternatif energi baru. Dengan penggabungan energi baru dan filtrasi air, maka akan menjadi solusi masalah listrik dan air besih.

Kegiatan pengabdian masyarakat pada peternakan ayam petelur di daerah sungai sipai Martapura Kalimantan Selatan bertujuan untuk memberikan solusi air bersih dengan penggunaan Portable Smart Water Treatment dan memanfaatkan panel surya.

\section{Metode}

Kegiatan Pengabdian masyarakat dilaksanakan melalui penelusuran masalah air bersih, mencarian sumber air terdekat dari kandang ayam, penghitungan sumber tenaga, penghitungan debit air, pemasangan smartwater treatment dan pemberian modul penggunaan.

Penelusuran masalah air bersih dilakukan dengan wawancara dan observasi. Wawancara dilakukan pada peternak ayam petelur desa Sungai Sipai Kecamatan Martapura Kabupaten Banjar Kalimantan Selatan. Sedangkan observasi dilakukan dengan mengambil sample air yang menjadi sumber air yang akan ditreatment menjadi air bersih dalam kegiatan ini.

Mencari sumber air dilakukan dengan observasi, memperhitungkan posisi sumber air 
dan letak kendang ayam petelur. Hal ini agar dapat memperhitungkan jarak dan tenaga yang dibutuhkan perangkat agar dapat berjalan dengan baik.

Penghitungan sumber tenaga yaitu menghitung kebutuhan tenaga listrik dengan memperhatikan kebutuhan setiap perangkat dan kebutuhan dari proses yang akan dilakukan oleh portable smartwater treatment tenaga surya. Selanjutnya dengan menganalisis tenaga listrik yang dihasilkan oleh panel surya, menganalisis total kebutuhan listrik oleh perangkat dan menganalisis proses pengisian daya pada baterai.

Penghitungan debit air dengan memperhatikan besaran tandon, panjang pipa dan tinggi pengisian air. Dengan melakukan observasi ditentukan waktu yang dibutuhkan untuk mengisi tandon 1300 L yaitu sekitar 3 jam.

Pemasangan portable smartwater treatment tenaga surya dengan melibatkan mahasiswa dan peternak ayam petelur. Dari sumber air sumur menuju tandon pengisian air.

Selanjutnya pemberian modul penggunaan kepada pemberian modul penggunaan agar penggunaannya dapat dilakukan oleh peternak ayam petelur desa Sungai Sipai Kecamatan Martapura Kabupaten Banjar Kalimantan Selatan.

\section{Hasil dan Pembahasan}

Teknologi merupakan salah satu alternatif untuk mengatasi masalah yang dihadapi masyarakat. Teknologi tersebut berpotensi memenuhi beberapa kriteria antara lain : (a) mengkonversi sumberdaya alam, (b) menyerap tenaga kerja, (c) memacu industri rumah tangga, dan (d) meningkatkan pendapatan masyarakat.
Penerapan Energi baru dan terbarukan dengan filtrasi dalam Smartwater Treatment Portable pada peternakan ayam petelur bertujuan untuk meningkatkan kualitas dan kuantitas dari produksi telur. Sumber air yang digunakan adalah air gambut wilayah sungai sipai Martapura Kaliamantan Selatan.

Smartwater Treatment Portable adalah teknologi yang mudah digunakan dan dengan konsumsi listrik dengan memanfaatkan tenaga baru dan terbarukan dari tenaga surta, sehingga dapat menekan pengeluaran listrik. Peralatan Smartwater Treatment Portable tersebut adalah pompa air sedot (Gambar 1), pompa air dorong (gambar 2), panel surya (gambar 3), controller daya (gambar 4) dan filter air (gambar 5).

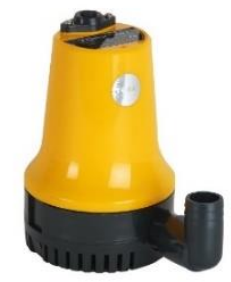

Gambar 1. Pompa Sedot / celup

Pompa sedot ini adalah alat yang digunakan untuk memindahkan cairan atau (fluida) dari suatu tempat ke tempat lainya melalui saluran (pipa) dengan menyedot dari dalam sumur. Pompa ini disebut juga pompa celup karena pompa ini akan langsung dicelupkan di dalam sumber air.

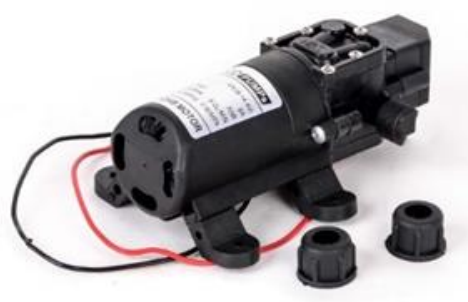

Gambar 2. Pompa dorong

Pompa dorong ini adalah alat yang digunakan untuk mendorong cairan atau 
(fluida) dari suatu tempat ke tempat lainya melalui saluran (pipa) dengan memompa air menjadi lebih deras.

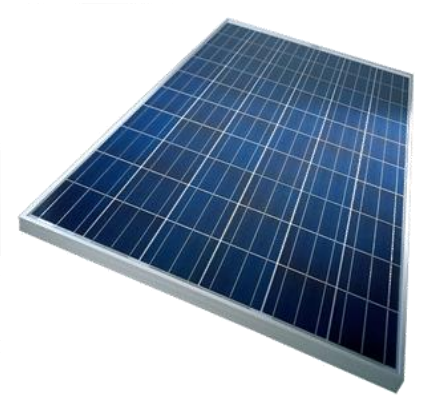

Gambar 3. Panel surya

Panel surya digunakan untuk menangkap sumber tenaga surya untuk membangkitkan tenaga listrik. Panel surya tersebut akan mengisi tenaga dalam baterai maksimal menjadi maksimal.

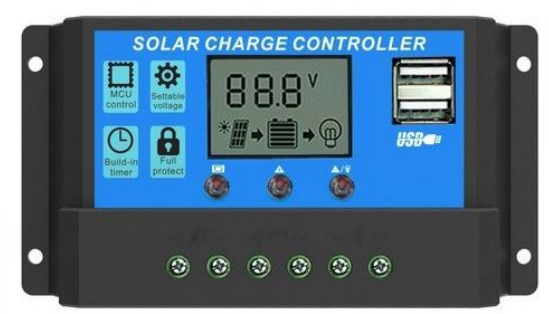

Gambar 4. Controller

Controller ini digunakan untuk mengontrol sumber tenaga dari panel surya dan mengatur pengisian dalam baterai. Indikator akan menunjukkan informasi pengisian panel surya dan pengisian pada baterai.

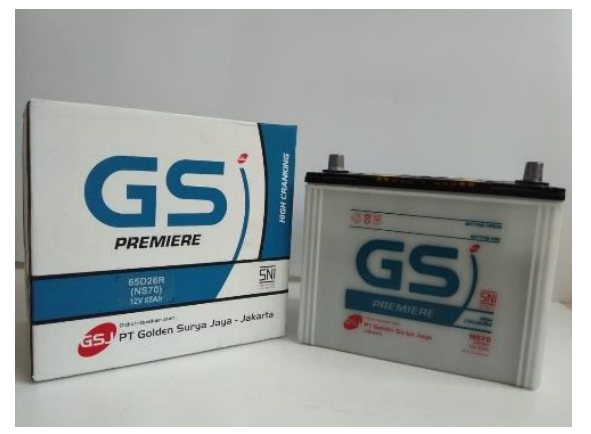

Gambar 5. Baterai
Baterai ini merupakan penyimpanan tenaga untuk dapat digunakan dalam menghidupkan pompa.

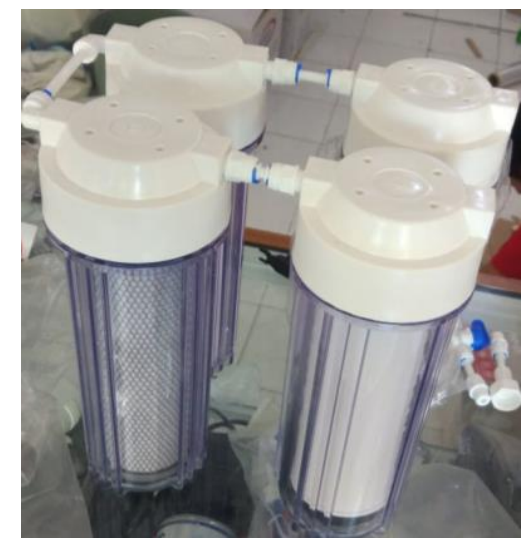

Gambar 6. Portable filter

Perangkat filtrasi yang akan memfiter air gambut menjadi air bersih. Filter terdiri dari 4 bagian yang memiliki fungsi masing-masing. Filter pertama adalah filter sedimen dengan ukuran 0,5 micron untuk menyaring endapan kasar, filter ke dua adalah filter sedimen dengan ukuran 0,3 micron untuk menyaring endapan halus, filter ketiga adalah filter granular activated carbon (GAC) yang berisi butiran karbon akif untuk menyaring senyawa polutan dan kimia yang dapat mengakibatkan bau dan rasa, filter ke empat adalah filter Chlorine, Taste, and Odor (CTO) yang berisi karbon aktif yang dipadatkan sehingga menyaring senyawa polutan dan kimia yang dapat mengakibatkan bau dan rasa untuk tahap lanjutan setelah filter GAC.

Hasil penerapan dari smartwater treatment maka menghasilkan air dengan kadar sebagai berikut, berdasarkan hasil pengujian air di lab dasar FMIPA ULM :

Tabel 1. Hasil Uji Lab

\begin{tabular}{cccc}
\hline Indikator & sebelum & sesudah & standar \\
\hline kekeruhan & $105 \mathrm{NTU}$ & $1 \mathrm{NTU}$ & Maks 5 \\
\hline TSS & 148 & 10 & maks 50 \\
\hline PH & 5,78 & 6,38 & $6-9$ \\
\hline
\end{tabular}




\begin{tabular}{llll}
\hline TDS & 289 & 77 & 1000 \\
\hline
\end{tabular}

Berdasarkan hasil wawancara terhadap peternak ayam petelur sungai sipai martapura, maka terjadi peningkatan hasil produksi sekitar 5\%, dari sekitar $75 \%$ menjadi $85 \%$ hasil produksi ayam petelur.

\section{Penutup}

Melalui kegiatan penerapan teknologi smartwater treatment portable, maka telah mampu meningkatkan produksi ayam petelur 5\%. Dari rata-rata 1000 butir perhari menjadi 1050 perhari. Dengan kebersihan air maka kesehatan ayam menjadi lebih baik dan meningkatkan produksi.

Saran hasil penerapan ini dapat dikembangkan lagi penggunaan pada air siap minum dan penggunaan listrik rumah.

\section{DAfTAR PUstaka}

Abrori, Muchammad; Sugiyanto; Niyartama, Thaqibul F. (2017). Pemanfaatan Solar Cell Sebagai Sumber Energi Alternatif dan Media Pembelajaran Praktikum Siswa Di Pondok Pesantren "Nurul Iman" Sorogenen Timbulharjo, Sewon, Bantul, Yogyakarta Menuju Pondok Mandiri Energi. Yogyakarta : Jurnal Bakti Saintek.

Julisman, Andi; Sara, Ira D; Siregar, Ramdhan H. (2017). Prototipe Pemanfaatan Panel Surya Sebagai Sumber Energi Pada Sistem Otomasi Atap Stadion Bola. Jurnal Online Teknik Elektro. Banda Aceh : Kitektro.

Maysha, Ima; Trisno, Bambang; Hasbullah. (2013). Pemanfaatan Tenaga Surya Menggunakan Rancangan Panel Surya Berbasis Transistor 2n3055 Dan
Thermoelectric Cooler. Bandung Electrans.

\section{Riwayat Hidup Penulis}

\section{Dodon Turianto Nugrahadi, S.Kom, M.Eng}

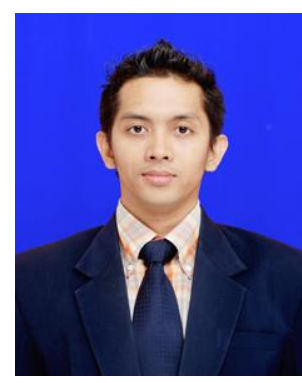

Lahir di Banjarmasin, 12 Januari 1980. Staf pengajar di Program Studi Ilmu Komputer, Fakultas MIPA, Universitas Lambung Mangkurat. Studi S1 Teknik Informatika Universitas Petra, Surabay, lulus tahun 2005; S2 Teknologi Informasi Universitas Gadjah Mada, Yogyakarta, lulus tahun 2008.

\section{Liling Triyasmono, S.Farm, M.Sc, Apt}

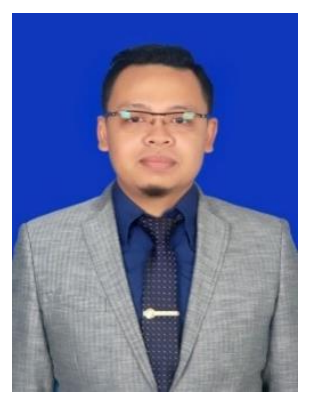

Lahir di Wonogiri, 23 Desember 1982. Staf pengajar di Program Studi Farmasi, Fakultas MIPA, Universitas Lambung Mangkurat. Studi S1 Farmasi Universitas Setia Budi, Solo, lulus tahun 2005; S2 Farmasi Universitas Gadjah Mada, Yogyakarta, lulus tahun 2013. 